DOI: $10.19195 / 0080-3626.60 .7$

ANNA GRUCA

\title{
BADANIA NAD KSIĄŻKĄ I JEJ RODZAJAMI W POLSCE PO II WOJNIE ŚWIATOWEJ
}

\begin{abstract}
Morfologia książki i cechy poszczególnych jej rodzajów. Badania nad poszczególnymi rodzajami książki: naukową, popularną, dla dzieci i młodzieży. Prace poświęcone poszczególnym rodzajom książki. Literatura z pogranicza bibliologii i innych dyscyplin.
\end{abstract}

SŁOWA KLUCZOWE: badania nad książką, budowa książki, typologia książki

Podejmowane po roku 1945 próby podsumowania dorobku i oceny polskiej bibliologii sporządzane były według pewnego schematu. Ich autorzy omawiali dokonania w zakresie poszczególnych subdyscyplin bibliologii, osobno traktując książkę rękopiśmienną, osobno drukowaną. Podsumowywano badania w dziedzinie historii papiernictwa, drukarstwa, księgarstwa, bibliotek, czytelnictwa. Niektórzy autorzy poświęcali także swoją uwagę zagadnieniom teoretycznym, oceniając tym samym całość obszaru badawczego bibliologii. Oczywiście takie ujęcie ma swoje uzasadnienie: pozwala stwierdzić, które z dziedzin wchodzących w zakres bibliologii najprężniej się rozwijają, jakie tematy dominują, a z drugiej strony — które cieszą się mniejszym zainteresowaniem badaczy. Z kolei przeglądy według chronologii przedmiotowej pokazują, jakie epoki w historii książki są szczególnie eksponowane w badaniach, a o których pisze się znacznie mniej ${ }^{1}$.

${ }^{1}$ M.in.: Paulina BUCHWALD-PELCOWA, Badania nad historia polskiej książki drukowanej XV-XVIII wieku, Przegląd Biblioteczny (42) 1974, z. 4, s. 371-390; Henryk BUŁHAK, Badania nad dziejami ksiażki polskiej wieków XVI-XVIII w okresie powojennym. Cz. 1, Rocznik Biblioteki Narodowej (4) 1968, s. 333-357; Marian J. LECH, Stan badań nad historia ksiażki polskiej 1850-1918, Przegląd Biblioteczny (42) 1974, z. 4, s. 403-411; Elżbieta SŁODKOWSKA, Problematyka badań nad historia książki polskiej XIX w., Studia o Książce (8) 1978, s. 69-80. W t. 12 Studiów o Książce wydrukowano referaty z konferencji Stan i perspektywy badań księgoznawczych w Polsce (Karpacz, 22-27 XI 1979 r.), podejmujące zagadnienia teorii (Krzysztof Migoń), historii ruchu wydawniczego (Elżbieta Słodkowska), edytorstwa (Jan Trzynadlowski), dziejów bibliotek i bibliotekarstwa (Zofia Gaca-Dąbrowska), bibliofilstwa (Stanisław Jerzy Gruczyński), czytelnictwa i jego historii (Kazimiera Maleczyńska, Teresa Radwan-Wińska). 
Możliwe jest jeszcze inne spojrzenie na problematykę badań bibliologicznych. Przyjmuje się, iż przedmiotem bibliologii ,jest książka, tak pojedyncza, jak i postrzegana jako idea lub zbiór książek"2. Panuje obecnie zgoda (nie tak oczywista dla niektórych teoretyków formułujących swoje koncepcje w okresie, gdy bibliologia rodziła się jako samodzielna dyscyplina) również co do tego, iż bibliologia swoim zakresem obejmuje zarówno materialną stronę książki, jak i jej treść (w określonych aspektach), tworzące pewną jedność. Typologia książki, jej budowa oraz różne jej rodzaje i ich historia powinny więc zajmować ważne miejsce w badaniach bibliologicznych. Autorka postawiła sobie za cel przeanalizowanie, czy i w jakim zakresie problematyka ta jest obecna w dorobku polskiej bibliologii po II wojnie światowej. Materiał badawczy został zebrany na podstawie „Polskiej Bibliografii Bibliologicznej” (wcześniej „Bibliografii Bibliografii i Nauki o Książce"). Pewną trudność stanowił fakt, iż bibliografia ta, zarówno w formie drukowanej, jak i elektronicznej bazy danych, obejmuje piśmiennictwo tylko do 2010 roku. Dlatego też, aby uzyskać informacje o później opublikowanych pracach, korzystano również z „Przewodnika Bibliograficznego”, „Bibliografii Zawartości Czasopism” oraz bieżącej „Bibliografii Historii Polskiej”. Publikacje z zakresu omawianej problematyki w „Polskiej Bibliografii Bibliologicznej” rejestrowane są głównie w dziale „Poszczególne dziedziny i typy wydawnictw”. Należy dodać, że niniejsze omówienie będzie dotyczyło prac podejmujących problematykę książki drukowanej i jej rodzajów w aspekcie historycznym. Wprawdzie jest również wiele opracowań poświęconych książce współczesnej, lecz odnoszą się one zazwyczaj do obecności różnych jej rodzajów na rynku wydawniczym: w repertuarze poszczególnych wydawców lub w ofercie księgarskiej. Skupiono się głównie na publikacjach z zakresu bibliologii, jednak wskazano też te z innych dziedzin, które przynoszą interesujące dla bibliologów wyniki i mogą być pomocne w badaniach księgoznawczych lub je inspirować. Przegląd literatury na temat badań nad poszczególnymi rodzajami książki rozpoczęto od tych prac, które zajmują się elementami książki, jej typologią, dążą do określenia cech poszczególnych jej typów. Następnie przedstawiono opracowania poświęcone różnym rodzajom książki, a szczególnie naukowej, dla dzieci i młodzieży oraz popularnej, które wyróżniają się spośród innych ilością. Starano się pokazać liczne aspekty prowadzonych w tym zakresie badań. Zwrócono wreszcie uwagę na publikacje z innych niż bibliologia dziedzin, które podejmują zagadnienia związane z poszczególnymi typami książki.

1. Prace dotyczące typologii książki, jej budowy, poszczególnych elementów nie pojawiały się zbyt często. Należy zacząć od podstawowej publikacji $-E n-$ cyklopedii wiedzy o książce. W indeksie rzeczowym nie ma odrębnego działu

${ }^{2}$ Krzysztof MIGOŃ, O przedmiocie badań wspótczesnej bibliologii, Konspekt (19) 2008, s. $27-29$. 
„Morfologia książki”; odsyłacz kieruje do działu „Wydawnicze zagadnienia”. Tam właśnie w poddziale „Wydawnictwa-publikacje” zebrano w dwóch grupach „Morfologia” i „Formy” - tego typu hasła. Natomiast w dziale „Bibliologia” w poddziale „Rodzaje, gatunki i typy piśmiennicze” znalazły się też hasła dotyczące różnych form książki drukowanej.

Zagadnienia związane z częściami składowymi książki poruszały podręczniki przeznaczone dla różnych poziomów kształcenia bibliotekarzy ${ }^{3}$. Obszerny rozdział poświęcony tej tematyce, autorstwa Janiny Pelcowej, znalazł się w Bibliotekarstwie naukowym pod redakcją Adama Łysakowskiego (Warszawa 1956).

Rozważania na temat budowy książki i jej rodzajów znalazły się w pracach niektórych teoretyków bibliologii, którzy pisząc o przedmiocie tej dyscypliny, podejmowali też zagadnienie morfologii książki. Problematyka taka pojawiła się w pracy Teoria bibliografii $w$ zarysie (Wrocław 1951) autorstwa jednego z prekursorów współczesnej bibliologii - Stefana Vrtela-Wierczyńskiego. Autor dokonał w niej podziału książek według różnych kryteriów oraz omówił części składowe książki. Wiele uwagi zagadnieniu kształtu typograficznego, kompozycji graficznej poświęcił w swoim najważniejszym dziele Ksiązka w procesie komunikacji społecznej (Wrocław 1980) Karol Głombiowski, wiążąc te elementy książki z jej funkcją. Problematyką budowy książki z punktu widzenia jej uczestnictwa w komunikacji społecznej zajmował się też Radosław Cybulski. W pracy Książka wspótczesna. Wydawcy - rynek - odbiorcy, biorąc pod uwagę miejsce i rolę książki w procesie komunikacji społecznej, przeanalizował jej części składowe według dziewięciu porządków, przez które rozumiał „zespół wybranych elementów składowych książki spełniający określone funkcje w procesie jej użytkowania"4. Wcześniej zagadnienia istoty i budowy książki poruszył w artykule Struktura i właściwości ksią̇ki . Cybulski skupiał się na książce współczesnej, natomiast właściwości książki w ich historycznym rozwoju przeanalizował Janusz Dunin w pracy Rozwój cech wydawniczych ksiązki literackiej (Łódź 1982). Jest to pierwsze w polskiej literaturze tak wszechstronne omówienie kształtowania się takich składników książki, jak karta tytułowa, aparat organizacji wewnętrznej, okładka, obwoluta. Mimo że autor koncentrował się na książce literackiej, to jednak wiele jego ustaleń ma wymiar ogólny i można je przyporządkować do każdego rodzaju książki. Dotyczy to choćby ukształtowania się elementów karty

${ }^{3}$ Np. Henryk DUBOWIK, Książka i czasopismo współczesne, Warszawa: Państwowy Ośrodek Kształcenia Korespondencyjnego Bibliotekarzy 1976; Ksawery ŚWIERKOWSKI, Morfologia ksiązki, Warszawa: Min. Kultury i Sztuki 1954. Z nowszych publikacji: Stanisław Adam KONDEK, Zagadnienia wydawnicze i księgarskie, Warszawa: Wydaw. SBP 2010. Zagadnienie to nie pojawiło się natomiast w najnowszym podręczniku: Bibliotekarstwo. Pod red. Anny Tokarskiej, Warszawa: Wydaw. SBP 2013.

${ }^{4}$ Radosław CYBULSKI, Ksią̇̇ka współczesna. Wydawcy-rynek-odbiorcy, Warszawa: PWN 1986, s. 54.

5 Studia o Książce (14) 1984, s. 3-38. 
tytułowej w XIX wieku ${ }^{6}$. Dunin ma też w swoim dorobku interesujący tekst dotyczący funkcji okładki i obwoluty książki ${ }^{7}$. Do artykułu tego nawiązała Katarzyna Szczęśniak, która pokazała możliwości badawcze, jakie stwarza spojrzenie na okładkę z punktu widzenia edytorstwa, nauki o komunikacji, jako dzieła sztuki i przedmiotu projektowania graficznego ${ }^{8}$. Innym, oprócz okładki i obwoluty, elementem budowy książki, którego badanie bibliologia dzieli z innymi naukami, jest ilustracja książki. Jest to jednak obszerne zagadnienie i dlatego wymaga odrębnego opracowania.

Przeglądu wypowiedzi na temat konieczności wiązania treści książki z jej formą zewnętrzną dokonała w 2009 roku Elżbieta Jamróz-Stolarska9 ${ }^{9}$. Jeszcze inne spojrzenie na kształt typograficzny książki zaproponowała Ewa Repucho jako wyznacznika jej tożsamości ${ }^{10}$. Zagadnienia kształtu typograficznego książki pojawiły się również w pracy zbiorowej $W$ poszukiwaniu odpowiedniej formy (Wrocław 2012). Jak wskazuje podtytuł, zebrane tu rozprawy mają ukazywać „rolę wydawcy, typografia, artysty i technologii w pracy nad książką". Dotyczą poszczególnych elementów książki (okładka, ilustracja) i ich funkcji, cech poszczególnych typów książki (artystyczna, dla dzieci i młodzieży), zarówno w kontekście historycznym, jak i współczesnym.

Trzeba ponadto zauważyć, iż problematyką budowy książki, jej elementami, porządkiem wewnętrznym zajmują się także podręczniki przeznaczone dla typografów oraz projektantów książki ${ }^{11}$.

2. Bibliolodzy starają się też określić cechy charakterystyczne poszczególnych rodzajów książki, pozwalające na ich precyzyjną identyfikację, tak aby jednoznacznie można było przyporządkować książki do pewnych repertuarów. Dotyczy to zwłaszcza książki naukowej, dla dzieci i młodzieży oraz popularnej.

${ }^{6}$ O karcie tytułowej w staropolskiej książce pisała Maria JUDA, Karta tytułowa staropolskiej ksiązki drukowanej, Odrodzenie i Reformacja w Polsce (46) 2002, s. 67-78.

7 Janusz DUNIN, Okładka i obwoluta jako komunikat. Wprowadzenie do problematyki, [w:] Sztuka książi, historia - teoria - praktyka. Pod red. Małgorzaty Komzy, Wrocław: Wydaw. Uniwersytetu Wrocławskiego 2003, s. 81-90.

8 J. DUNIN, Okładka i obwoluta książki jako przedmiot badań interdyscyplinarnych, Toruńskie Studia Bibliologiczne 2011, nr 2, s. 29-41.

9 Elżbieta JAMRÓZ-STOLARSKA, Architektura książki jako problem badawczy, [w:] Pierwszy Zjazd Edytorów, studentów i doktorantów. Polska-Ukraina, 02-04.04.2009, Kraków: Koło Naukowe Edytorów UJ 2010, s. 67-81.

10 Ewa REPUCHO, Ukształtowanie typograficzne jako atrybut kulturowej tożsamości ksią̇̇ki, [w:] Kulturowa tożsamość ksiązki. Pod red. Anny Cisło i Agnieszki Łuszpak, Wrocław: Wydaw. Uniwersytetu Wrocławskiego 2014, s. 75-86.

11 Np. Andrzej TOMASZEWSKI, Architektura ksiązki, Warszawa: Centralny Ośrodek Badawczo-Rozwojowy Przemysłu Poligraficznego 2011; Filip TRZASKA, Podstawy techniki wydawniczej, wyd. 2 popr. i uzup., Warszawa: Instytut Wydawniczy Związków Zawodowych 1987. 
Z problemem sprecyzowania właściwości książki naukowej borykają się badacze zajmujący się zarówno dawną, jak i współczesną książką tego typu. Zwracają uwagę na nieostrość kryteriów w tym zakresie ${ }^{12}$. Krzysztof Migoń przypisuje to trudnościom w sprecyzowaniu samych pojęć „nauka” i „książka”"13. On sam w tekście Historyczna typologia ksiażki naukowej przywołał kategoryzacje dokonane przez różnych autorów. Artykuł ten może stanowić punkt wyjścia dla badaczy zajmujących się także innymi rodzajami książki, albowiem autor przedstawił tu, powołując się na Alisę Biełowicką, kryteria typologii książki ${ }^{14}$. Na problemy terminologiczne niepozwalające na jednoznaczną typologię książki naukowej wskazał też Leon Marszałek w pracy Edytorstwo publikacji naukowych (Warszawa 1986), w której omówił ponadto różne rodzaje publikacji naukowych.

Trudności w precyzyjnym zdefiniowaniu książki naukowej sprawiają, że badacze zajmujący się nią, rozpoczynają zazwyczaj swoje rozważania od określenia, co będą rozumieć pod tym pojęciem. Dokonują też mniej lub bardziej dokładnej typologii książki naukowej. Pojawia się ona na przykład w pracy Anny Żbikowskiej-Migoń Książka naukowa w kulturze polskiego Oświecenia (Wrocław 1977).

Książka naukowa charakteryzuje się specyficznym ukształtowaniem typograficznym. Zagadnienie to również znalazło odzwierciedlenie w publikacjach A. Żbikowskiej-Migoń — we wspomnianej wyżej książce oraz w osobnym artykule ${ }^{15}$. Kwestią tą w odniesieniu do wcześniejszej epoki zajęła się Irena Rapacka, natomiast do współczesnej książki - Henryk Żeligowski, który powiązał to zagadnienie z problemem efektywności komunikacyjnej książki naukowej ${ }^{16}$. $\mathrm{Z}$ kolei artykuł Jana Kuźmy dotyczy jednego z aspektów budowy książki naukowej - ilustracji ${ }^{17}$.

Kolejnym rodzajem książki, którą wyróżnia zarówno adresat, jak i forma zewnętrzna, jest książka popularna i jej szczególny rodzaj — książka dla ludu.

12 Autorzy podejmujący zagadnienie książki naukowej w różnych aspektach, próbując zdefiniować na początku przedmiot swoich badań, podkreślają niejednoznaczność tego terminu. Zob. np. Małgorzata KORCZYŃSKA-DERKACZ, Ksią̇ka naukowa w Polsce w latach 1991-2005tendencje rozwojowe, Zagadnienia Informacji Naukowej 2006, nr 2 (88), s. 91-92.

${ }^{13}$ K. MIGOŃ, Historyczna typologia książki naukowej, [w:] Książka naukowa jako czynnik rozwoju cywilizacyjnego, Warszawa: SAP 1986, s. 5.

14 Ibidem.

15 Anna ŻBIKOWSKA-MIGOŃ, O potrzebie badań nad ksztattem edytorskim polskiej książki naukowej XVIII-XIX wieku z perspektywy funkcjonalności publikacji, [w:] Od ksiażki dawnej do biblioteki wirtualnej. Pod red. Doroty Degen i Małgorzaty Fedorowicz, Toruń: Wydaw. Naukowe UMK 2009, s. 165-186.

16 Irena RAPACKA, Typologia i struktura wewnętrzna książki naukowej w Polsce w latach 1650-1750, Rocznik Biblioteki Narodowej (26) 1993, s. 39-47; Henryk ŻELIGOWSKI, Uksztattowanie edytorsko-poligraficzne wspótczesnej książki naukowej - zarys problematyki, Roczniki Biblioteczne (36) 1992, z. 1/2, s. 19-36.

17 Jan KUŹMA, Materiat ilustracyjny jako element kompozycji edytorskiej w publikacjach naukowych w dziedzinie geografii, Ze Skarbca Kultury (32) 1979, s. 191-202. 
W tym przypadku również próbuje się określić wyróżniki pozwalające stwierdzić, że mamy do czynienia $\mathrm{z}$ tym rodzajem książki ${ }^{18}$. W literaturze utożsamia się niekiedy te dwa rodzaje i terminy: „książka dla ludu” i „książka popularna” występują zamiennie. Jak pisze Janusz Dunin, można w literaturze dla ludu wyróżnić dwa nurty: „płody pożytku” i „płody skandalu”. W tym pierwszym mieściłyby się publikacje, które stawiały sobie za cel podniesienie poziomu oświaty na wsi, w drugim zaś te, które przyciągały sensacją i skandalem. Dunin zwraca przy tym uwagę, iż często granice między tymi dwoma nurtami się zacierały ${ }^{19}$. Jedną z cech książki popularnej, w tym książki dla ludu, była odpowiednio dobrana treść. Literatura popularna wykształciła charakterystyczne dla niej gatunki, dlatego też nierzadko zamiennie używa się terminów „książka popularna” i „literatura popularna”. Takie ujęcie pojawia się w pracach Józefa Szockiego, m.in. w książce Literatura popularna dla ludu na przykładzie Wydawnictwa Ludowego 1882-1920 (Kraków 1994).

Kryterium wyróżniającym książkę dla dzieci i młodzieży jest przede wszystkim adresat, a także determinowana tym forma zewnętrzna. Specyficzne cechy książki dziecięcej opisał Michał Zając w monografii Promocja książki dziecięcej. Podręcznik akademicki (Warszawa 2000). Oparł się tutaj na zaproponowanym przez Radosława Cybulskiego, wspomnianym już, systemie dziewięciu porządków istniejących w książce, które decydują o jej materialnej postaci. Charakterystyki składających się na ten rodzaj książki elementów dokonała również Irena Socha w artykule Kształtowanie się cech wydawniczych polskiej ksiażki dla młodego odbiorcy ${ }^{20}$. Analizuje w nim takie cechy edytorskie, jak kategoria autora, wpisane w książkę informacje, źródło tekstu, intencje nadawcy, przeznaczenie, kategoria adresata, które sprawiają, że można na ich podstawie rozpoznać książkę dziecięcą. Ta sama autorka scharakteryzowała też książkę dla dzieci jako przedmiot badań ${ }^{21}$. Jej rozważania odnoszą się wprawdzie do książki funkcjonującej na Śląsku w drugiej połowie XIX i na początku XX wieku, jednak niektóre ustalenia mają charakter uniwersalny. Analogiczne zagadnienie, lecz w kontekście książki

18 Anna GRUCA, Cechy książi dla ludu na przełomie XIX i XX wieku, [w:] Kulturowa tożsamość książki. Pod red. Anny Cisło i Agnieszki Łuszpak, Wrocław: Wydaw. Uniwersytetu Wrocławskiego 2014, s. 179-191; eadem, Ksiązka dla ludu przełomu XIX i XX w. w opinii środowisk katolickich, [w:] Książka i biblioteka w procesie komunikacji społecznej, pod red. Renaty Aleksandrowicz, Haliny Rusińskiej-Giertych, Wrocław: Atut 2015, s. 139-153.

19 J. DUNIN, Wydawnictwa popularne w opinii publicznej na przełomie XIX i XX w., Przegląd Biblioteczny (33) 1965, z. 4, s. 229-238.

${ }^{20}$ Irena SOCHA, Kształtowanie się cech wydawniczych polskiej książki dla młodego odbiorcy, [w:] Dzieło literackie i ksiązka w kulturze. Pod red. Ireneusza Opackiego przy współudz. Bożeny Mazurkowej, Katowice: Wydaw. Uniwersytetu Śląskiego 2002, s. 469-481.

${ }^{21}$ I. SOCHA, ,Przykladne, użyteczne, zabawne”. O polskich ksiażkach dla młodego odbiorcy na Ślasku w drugiej połowie XIX i na początku XX wieku, Katowice: Wydaw. Uniwersytetu Śląskiego 2001, s. 7-28. 
współczesnej, przedstawiła Jadwiga Konieczna ${ }^{22}$. Zwróciła uwagę na zachodzące zmiany zarówno w warstwie tekstowej, jak i w formie zewnętrznej książki dla dzieci. To samo zjawisko, lecz dokonujące się pod wpływem nowych mediów, opisał Michał Zając ${ }^{23}$.

3. Wśród opracowań poświęconych różnym rodzajom książki przeważają te dotyczące książki dla dzieci oraz naukowej. Niewiele jest jednak takich, które całościowo zajmują się książką określonego typu w pewnym okresie historycznym, charakteryzujących jej cechy zewnętrzne i treściowe, kategorie, repertuary. W odniesieniu do książki naukowej wyjątkowe miejsce zajmuje wspomniana już rozprawa Anny Żbikowskiej-Migoń. Autorka kompleksowo zbadała obecność książki naukowej w Polsce w okresie Oświecenia. Zajęła się warunkami produkcji (przedstawiła jej rozmiar, także według poszczególnych ośrodków i oficyn typograficznych), sposobami informacji oraz rozpowszechnianiem książki naukowej i jej użytkowaniem. Książka naukowa innych epok nie doczekała się dotychczas tak całościowej analizy. Pojawiają się natomiast opracowania dotyczące zagadnień publikowania i rozpowszechniania książki naukowej. Jest ona rozpatrywana jako element repertuaru wydawniczego w różnych okresach i ośrodkach. Można tu wskazać na przykład cykl artykułów Magdaleny Kwiatkowskiej, charakteryzujący ofertę książki naukowej w Warszawie i w prowincjonalnych ośrodkach Królestwa Polskiego w XIX wieku ${ }^{24}$, czy też rozprawę Anny Aleksiewicz omawiającą to zagadnienie $\mathrm{w}$ odniesieniu do zaboru austriackiego ${ }^{25}$. Kwiatkowska zajęła się ponadto problemem rozpowszechniania książki naukowej na tym terenie ${ }^{26}$. Jeden z jego sposobów w pierwszej połowie XIX wieku — prenumeratę — przedstawiła

22 Jadwiga KONIECZNA, Współczesna książka dziecięca - nowe zjawisko kulturowe i nowy obiekt badawczy, [w:] Historia i wspótczesność w badaniach bibliologicznych, pod red. Jadwigi Koniecznej, Łódź: Wydaw. Ibidem 2007, s. 149-157.

${ }_{23}$ Michał ZAJĄC, Książka dziecięca - w stronę konwergencji mediów, [w:] Biblioteka, książka, informacja 2010. Pod red. Zbigniewa Osińskiego, Lublin: Instytut Bibliotekoznawstwa i Informacji Naukowej UMCS 2010, s. 101-112.

24 Magdalena KWIATKOWSKA, Książka naukowa w repertuarze wydawców prowincjonalnych Królestwa Polskiego (1815-1914), Sprawozdania z Czynności i Posiedzeń Naukowych (57) 2003, s. 159-168; eadem, Książka naukowa w repertuarze wydawców warszawskich w drugiej połowie XIX wieku. Piśmiennictwo dyscyplin humanistycznych, Acta Universitatis Lodziensis. Folia Librorum (10) 2007, s. 39-56; eadem, Piśmiennictwo naukowe w repertuarze wydawców lubelskich na tle prowincjonalnych ośrodków wydawniczych Królestwa Polskiego, [w:] Lublin a ksiażka, pod red. Antoniego Krawczyka i Elżbiety Józefowicz-Wisińskiej, Lublin: Lubelskie Towarzystwo Naukowe 2004, s. 415-429.

25 Anna ALEKSIEWICZ, Charakterystyka repertuaru wydawniczego książki naukowej w zaborze austriackim w latach 1815-1860, Studia o Książce (10) 1980, s. 73-111.

26 M. KWIATKOWSKA, Udziat redakcji warszawskich czasopism kulturalno-społecznych w rozpowszechnianiu książki naukowej w drugiej połowie XIX i na początku XX wieku, Acta Universitatis Lodziensis. Folia Librorum (12) 2005, s. 5-33. 
też Anna Dymmel ${ }^{27}$. Z kolei Andrzej Mężyński podjął zagadnienie finansowania książki naukowej jako przejaw XIX-wiecznego mecenatu ${ }^{28}$.

Powstały także publikacje poświęcone poszczególnym typom książki naukowej29. Należałoby w tym miejscu wspomnieć o pracy Staropolskie kompendia wie$d z y$ (Warszawa 2009), która wprawdzie ujmuje to zagadnienie z punktu widzenia historii literatury (tom ukazał się w cyklu „Staropolskie Teksty Paraliterackie”), lecz przynosi też informacje wartościowe dla badań bibliologicznych, charakteryzując konkretne przykłady takich publikacji. Interesujący pod tym względem jest zwłaszcza tekst Jana Okonia Kompendium - czy tylko wiedzy? Wstęp do typologii gatunku, otwierający ten tom. Prezentuje historyczny rozwój takich form, jak słowniki czy encyklopedie, które z jednej strony są wynikiem rozwoju wiedzy, a z drugiej mają tę wiedzę uprzystępniać.

W przypadku książki dla dzieci i młodzieży również więcej jest opracowań rozpatrujących różne szczegółowe zagadnienia z nią związane niż dokonujących jej kompleksowej charakterystyki, na przykład w określonej epoce. Wyjątek stanowi monografia Janusza Dunina Ksiązeczki dla grzecznych i niegrzecznych dzieci (Wrocław 1991), charakteryzująca formę, treść, panujące tendencje w odniesieniu do książki dziecięcej. Do tego typu opracowań należy też praca Ireny Sochy „Przykładne, użyteczne, zabawne”. O polskich książach dla młodego odbiorcy na Ślasku w drugiej połowie XIX i na poczatku XX wieku (Katowice 2001). Książka dla dzieci i młodzieży pojawia się w rozprawach również jako element repertuaru wydawniczego: określonych nakładców ${ }^{30}$, okresu historycznego ${ }^{31}$ czy kategorii książek ${ }^{32}$.

27 Anna DYMMEL, Rola kolektorów w rozprowadzaniu subskrypcji piśmiennictwa naukowego w pierwszej połowie XIX wieku, [w:] Bibliologia dyscyplina integrujaca. Red. Marianna Mlekicka, Warszawa: Wydaw. IHNOiT 1993, s. 253-258.

28 Andrzej MĘŻYŃSKI, Czy istniat mecenat wydawniczy wobec książki naukowej w XIX wieku?, [w:] Bibliologia dyscyplina integrująca, s. 81-86.

29 Np. A. ŻBIKOWSKA-MIGOŃ, Dysertacje akademickie — kłopotliwy typ książki naukowej, Rocznik Gdański (61) 2001, z. 2, s. 285-295.

${ }^{30} \mathrm{~Np}$. Michał ROGOŻ, Książka dla dzieci i młodzieży w repertuarze Wydawnictwa Literackiego (1953-1989), [w:] Kraków - Lwów, t. 11: Książki XIX-XX wieku. Pod red. Władysława Marka Kolasy, Iwony Pietrzkiewicz, M. Rogoża, Kraków: Księgarnia Akademicka 2014, s. 65-75; Ewa WÓJCIK, Książka dla dzieci i młodzieży w ofercie wydawców lwowskich w okresie dwudziestolecia międzywojennego, Acta Universitatis Pedagogicae Cracoviensis. Studia ad Bibliothecarum Scientiam Pertinentia (12) 2014, s. 19-37.

31 Jadwiga KOWALEWSKA, Edycje literatury dziecięco-młodzieżowej w latach pierwszej wojny światowej, Litteraria (21) 1989, s. 53-69; Krzysztof WOŹNIAKOWSKI, Książka dla dzieci w ofercie wydawniczej środowiska polskich uchodźców na Węrzech okresu II wojny światowej, Acta Universitatis Pedagogicae Cracoviensis. Studia ad Bibliothecarum Scientiam Pertinentia (12) 2014, s. 69-85.

32 Elżbieta GONDEK, Edycje książek literackich dla dzieci z pierwszej połowy XIX wieku, wydane w oficynach śląskich w granicach Prus, [w:] Młody czytelnik w świecie ksiażki, biblioteki i informacji. Pod red. Krystyny Heskiej-Kwaśniewicz i Ireny Sochy, Katowice: Wydaw. Uniwer- 
Specjalnym rodzajem książki dla dzieci i młodzieży są podręczniki. Problematyka z nimi związana ujmowana jest różnorako. Pisze się o ich repertuarze, historii, rodzajach ${ }^{33}$. Ilościowo wyróżniają się opracowania dotyczące elementarzy ${ }^{34}$.

4. Poza książką naukową oraz dla dzieci i młodzieży więcej uwagi poświęca się jeszcze książce popularnej (w tym dla ludu) oraz religijnej.

Zainteresowanie bibliologów książką popularną, w tym publikacjami jarmarcznymi, odpustowymi, straganowymi, pojawiło się stosunkowo niedawno. W artykule omawiającym warsztat badacza książki popularnej Janusz Dunin upominał się o bibliografię takich druków: powieści zeszytowej, pieśni nowiniarskich, ulicznych, senników i innych, którą uważał za podstawę i punkt wyjścia do badań nad tym rodzajem publikacji. Zwracał jednocześnie uwagę na problemy z jej opracowaniem wynikające między innymi z trudności dotarcia do tych druków. Uważane niegdyś za mało wartościowe, nie były gromadzone przez biblioteki,

sytetu Śląskiego 1996, s. 42-50; Anna NIKLIBORC, Francuska ksią̇ka w rękach młodzieży polskiej w wieku Oświecenia, Studia o Książce (7) 1977, s. 115-128; eadem, Francuska książka dla młodzieży w Polsce w wieku XIX, Studia o Książce (8) 1978, s. 123-136; Iwona PIRÓG, Ksiażka popularnonaukowa dla dzieci i młodzieży na ziemiach polskich $w$ latach 1830-1863, Studia o Książce (13) 1983, s. 77-110; Bogumiła STANIÓW, O polskiej ksiażce literackiej dla dzieci i młodzieży thumaczonej na języki obce w XIX wieku, Roczniki Biblioteczne (47) 2003, s. 68-88; eadem, Z uśmiechem przez wszystkie granice. Recepcja wydawnicza przekładów polskiej ksiązki dla dzieci i młodzieży w latach 1945-1989, Wrocław: Wydaw. Uniwersytetu Wrocławskiego 2006.

33 Np. Mieczysława ADRIANEK, Losy książek szkolnych w Królestwie Polskim po powstaniu listopadowym, Roczniki Biblioteczne (24) 1980, z. 1, s. 221-256; eadem, O ksiązkach elementarnych w czasach Księstwa Warszawskiego i Królestwa Polskiego, Przegląd Historyczno-Oświatowy (22) 1979, nr 1, s, 18-38; R. CYBULSKI, Podręczniki szkolne w wileńskim okręgu szkolnym w latach 1803-1831, Rocznik Biblioteki Narodowej (10) 1974, s. 181-201; Janina JAWORSKA, Łódzkie wydawnictwa podręcznikowe (do 1918 r.), Roczniki Biblioteczne (14) 1970, z. 1/2, s. 330-350; Artur JAZDON, Podręczniki w ofercie wydawców poznańskich (1831-1862), Kronika M. Poznania 2001, nr 4, s. 179-190; Aleksandra MENDYKOWA, Polski podręcznik $i$ ksiażka dla młodzieży w repertuarze wroctawskich oficyn wydawniczych w XIX w., Roczniki Biblioteczne (31) 1987, z. 2 s. 31-67; Jerzy RONIKIER, Szkolny podręcznik historii - szczególny rodzaj ksiązki. Podręczniki do szkól średnich w okresie 1920-1990, [w:] Biblioteka i informacja w komunikowaniu. Pod red. Marii Kocójowej, Kraków: Wydaw. UJ 2000, s. 200-209; Otylia SŁOMCZYŃSKA, Polsko-niemieckie podręczniki szkolne w czasach pruskich na Górnym Ślasku, Roczniki Biblioteczne (26) 1982, z. 1/2, s. 23-40; Józef WOJTAL, Wydawnictwo Ksiażek Szkolnych w Zakładzie Narodowym imienia Ossolińskich w latach 1878-1918, Wrocław: Zakład Narod. im. Ossolińskich 1976.

34 Np. Wiktor FRĄCKOWIAK, Wydawnictwa z zakresu elementarnej nauki języka polskiego na Pomorzu Gdańskim w latach 1840-1920, Gdańsk: Ossolineum 1977; Bronisław KOCOWSKI, Zagadkowy elementarz wrocławski, Rocznik Biblioteki Narodowej (4) 1968, s. 225-233; Franciszek PILARCZYK, Elementarze polskie od ich XVI-wiecznych początków do II wojny światowej. Próba monografii księgoznawczej, Zielona Góra: Oficyna Wydawnicza Uniwersytetu Zielonogórskiego 2003; Gertruda SKOTNICKA, Dawne i współczesne książki o literach, W Kręgu Książki (5) 1986, s. 7-21. 
a ze względu, z jednej strony, na duże zainteresowanie odbiorów i niski poziom edytorski z drugiej - zostały niemal zupełnie zaczytane, co wobec niestarannych opisów w katalogach publikujących je wydawców sprawia, że niemożliwe jest odtworzenie pełnego repertuaru $\mathrm{w}$ tym zakresie ${ }^{35}$. O potrzebie takiej bibliografii pisał też Władysław Chojnacki, powołując się na badania Dunina ${ }^{36}$. Sam Dunin był autorem dwóch spisów bibliograficznych opartych na własnej kolekcji: Polska powieść zeszytowa (wspólnie z Krystyną Mierzwianką, Wrocław 1978) oraz Polskie powieściowe serie zeszytowe (wspólnie ze Zdzisławem Knorowskim, Łódź 1984). Stanowią one oczywiście materiał pomocniczy do dalszych badań. Jednakże z dorobku Janusza Dunina należy przede wszystkim wymienić książkę Papierowy bandyta (Łódź 1974), która prezentuje różne rodzaje książki (literatury) jarmarcznej. Jest ona wersją jego rozprawy doktorskiej, mającej pionierskie znaczenie dla badań nad książką popularną w Polsce. Istotny dla badaczy tego nurtu jest też artykuł Dunina Książka i czytelnictwo popularne. Przyczynek do polskiego słownictwa księgoznawczego ${ }^{37}$, albowiem zawiera on propozycję definicji najważniejszych terminów związanych z książką i literaturą popularną.

Warto jeszcze wspomnieć o jednym artykule Janusza Dunina: Wydawnictwa popularne w opinii publicznej na przetomie XIX $i X X w^{38}$. Stanowi on wprowadzenie do problematyki wydawnictw dla ludu, podaje ich typologię, a także przytacza wiele wypowiedzi przedstawicieli różnych środowisk na temat treści oraz formy tego rodzaju książki.

Janusz Dunin pomijał w swoich rozważaniach książki popularne o treści dewocyjno-modlitewnej. Zagadnienie to podjął w swoich pracach Tomasz Ratajczak $^{39}$. Zajął się szczególnie modlitewnikami, które - wydawane często bez aprobaty cenzury kościelnej przez nakładców specjalizujących się w literaturze popularnej - funkcjonowały w obiegu jarmarczno-odpustowym ${ }^{40}$. Ten sam autor dokonał również typologii popularnej książki religijnej¹ .

35 J. DUNIN, Warsztat bibliograficzny i biblioteczny badacza literatury tandetnej, Studia o Książce (1) 1970, s. 117-131; przedr. w: idem, Studia o komunikacji społecznej, Łódź: Wyższa Szkoła Humanistyczno-Ekonomiczna 2004, s. 80-100.

36 Władysław CHOJNACKI, O bibliografię literatury straganowej, [w:] Z problemów bibliografii. Red. Maria Lenartowicz, Janina Pelcowa, Henryk Sawoniak, Warszawa: Biblioteka Narodowa 1970, s. 329-342.

37 Roczniki Biblioteczne (15) 1971, z. 1/2, s. 349-362.

38 Przegląd Biblioteczny (33) 1965, z. 4, s. 229-238.

39 Tomasz RATAJCZAK, Ksią̇ki religijne i quasi-religijne z wadowickich oficyn drukarskich (1825-1940), Warszawa: DiG 2010.

40 T. RATAJCZAK, Modlitewniki rzymskokatolickie $w$ galicyjskim obiegu jarmarczno-odpustowym (XIX-XX w.), [w:] Kraków - Lwów. Ksiązki, czasopisma, biblioteki XIX i XX w., t. 9, cz. 1. Pod red. Haliny Kosętki, Barbary Góry, Ewy Wójcik, Kraków: Wydaw. Naukowe Uniwersytetu Pedagogicznego 2009, s. 100-108.

${ }^{41}$ T. RATAJCZAK, Od modlitewnika do sennika. Książka religijna i quasi-religijna w galicyjskich obiegach popularnych w XIX wieku. Próba typologii, Literatura Ludowa (54) 2010, nr 1, s. 51-59. 
Do problematyki związanej z książką popularną należy zaliczyć również kwestię taniej książki, przeznaczonej dla szerokich warstw ludności. W tym zakresie można wskazać prace Marii Konopki, przede wszystkim książkę Tanie wydania literatury pięknej w Galicji i Wolnym Mieście Krakowie w latach 1822-1863 (Kraków 1987). Autorka wszechstronnie scharakteryzowała ten rodzaj publikacji, prezentując zarówno repertuar, jak i mającą istotne znaczenie dla ceny książek ich postać edytorską i typograficzną. M. Konopka poświęciła temu zagadnieniu także kilka artykułów ${ }^{42}$

Osobnym rodzajem książki popularnej jest ta przeznaczona dla ludu. Pojawiła się on w XIX wieku jako wynik działalności powstających głównie w ostatniej ćwierci tego wieku towarzystw oświatowych. Ten rodzaj książki badany jest z różnych punktów widzenia: jej typów ${ }^{43}$, treści ${ }^{44}$, nakładców ${ }^{45}$ oraz geografii wydawniczej ${ }^{46}$.

42 Staropolskie teksty literackie w tanich wydawnictwach krakowskich w latach 1822-1863, Rocznik Naukowo-Dydaktyczny WSP w Krakowie, z. 89, Prace Bibliotekoznawcze, Kraków 1984, s. 61-78; Tanie serie wydawnicze w Galicji doby zaborów, [w:] Wspólnota pamięci. Pod red. Jolanty Gwioździk, Jana Malickiego, Katowice: Biblioteka Śląska 2006, s. 159-172; Upowszechnianie tekstów literackich w Wielkim Księstwie Poznańskim w latach 1822-1863 za pośrednictwem tanich edycji, Studia o Książce (18) 1989, s. 139-172.

${ }^{43} \mathrm{~Np}$. Bronisława WOŹNICZKA-PARUZEL, „Dzieje ojczyste dla ludu” doby romantyzmu, Wrocław: Ossolineum 1990.

${ }^{44} \mathrm{~Np}$. Danuta ADAMCZYK, Literatura piękna w wydawnictwach dla ludu na przykładzie lwowskiego wydawnictwa ,Macierz Polska” (1882-1914/1918), [w:] Książa, biblioteka, informacja. Między podziałami a wspólnota. Pod red. Jolanty Dzieniakowskiej, Kielce: Wydaw. Akademii Świętokrzyskiej 2007, s. 73-79; Józef HEMPEL, Autorzy i wydawcy publikacji ,grunwaldzkich”, dla ludu w Galicji. Próba charakterystyki motywacji ideowo-politycznych, Rocznik Naukowo-Dydaktyczny WSP w Krakowie. Prace Historyczne z. 18, Kraków 1997, s. 71-84; B. WOŹNICZKA-PARUZEL, Koncepcje polskiego piśmiennictwa historiograficznego dla ludu w pierwszej połowie XIX w., Acta Universitatis Nicolai Copernici. Filologia Polska 19. Nauki Humanistyczno-Społeczne, z. 119, Toruń 1981, s. 17-34.

45 Józef SZOCKI, Komitet Wydawnictwa Dziełek Ludowych we Lwowie (1881-1920), Przegląd Wschodni 2009, s. 763-784; idem, Książki dla ludu i ich upowszechnianie na podstawie dziatalności Wydawnictwa Ludowego 1882-1920, Rocznik Naukowo-Dydaktyczny WSP w Krakowie. Prace Bibliotekoznawcze z. 135, Kraków 1990, s. 7-39; idem, Powiastka dla ludu na przykładzie Wydawnictwa Ludowego (wersja polska) 1882-1920, Litteraria (21) 1989, s. 37-51; idem, Wydawnictwo Ludowe - popularna seria książek dla ludności polskiej w Galicji (1882-1920), Ze Skarbca Kultury (50) 1990, s. 89-102; idem, Wydawnictwo Ludowe (1882-1920) - seria ksiazzek dla wsi galicyjskiej i jej rozpowszechnianie, Księgarz 1988, nr 3, s. 6-15; idem, Książka popularna dla ludu (na przyktadzie „,Macierzy Polskiej” 1883-1920), [w:] Ksiązka i prasa w systemie komunikacji społecznej. Pod red. Marii Judy, Lublin: Wydaw. Uniwersytetu Marii Curie-Skłodowskiej 2002, s. 61-67.

46 Grażyna GZELLA, Lwowskie inicjatywy książi dla ludu z połowy XIX wieku, [w:] Kraków - Lwów. Książki, czasopisma, biblioteki, t. 4. Pod red. Jerzego Jarowieckiego. Kraków: Wydaw. Naukowe WSP 1999, s. 34-45; Stanisław REYMONT, Warszawskie wydawnictwa popularne w latach 1880-1914, [w:] Z dziejów książki i bibliotek w Warszawie. Pod red. Stanisława Tazbira, Warszawa: PIW 1961, s. 385-432.

Roczniki Biblioteczne 60, 2016

(C) for this edition by CNS 
Pod pojęciem książki religijnej kryją się zarówno naukowe dzieła teologiczne i dotyczące historii Kościoła, jak i modlitewniki, życiorysy świętych, literatura dewocyjna ${ }^{47}$. Tę różnorodność pokazuje praca Tomasza Ratajczaka Książki religijne i quasi-religijne z wadowickich oficyn drukarskich (1825-1940) (Warszawa 2010): oprócz książek kanonicznych przedstawił typowe dla obiegu ludowego, które nazwał quasi-religijnymi. Zaliczył do nich pieśni, modlitewniki, katechizmy, kazania, apokryfy, legendy hagiograficzne książki profetyczne oraz zbadał między innymi ich cechy literackie i wydawnicze.

Spośród różnych typów książki religijnej najwięcej uwagi poświęcono tym, które wyróżniają się też formą zewnętrzną: modlitewnikom ${ }^{48}$, kancjonałom $^{49}$, śpiewnikom ${ }^{50}$, mszałom $^{51}$, a ponadto katechizmom ${ }^{52}$. Prezentowano też repertuar książki religijnej konkretnego nakładcy, w określonym czasie czy na pewnym terenie $^{53}$, badaniami tymi obejmując nie tylko książkę katolicką, lecz także protestancką i prawosławną ${ }^{54}$. Obecnie coraz bardziej widoczny jest także nurt badań

47 Aleksandra WITKOWSKA, Książa dewocyjna w duszpasterskiej postudze jasnogórskiego sanktuarium w XVII-XVIII wieku, Studia Claromontana (7) 1987, s. 50-60; Hanka ŻEREK, Ilościowy udzial literatury dewocyjnej $w$ rozwoju polskiego ruchu wydawniczego w XVIII w. Acta Universitatis Lodziensis. Zeszyty Naukowe Uniwersytetu Łódzkiego. Nauki Humanistyczno-Społeczne, Ser. I, 1979, nr 57, s. 141-149.

48 Józef BAKAŁARZ, Polskie modlitewniki na emigracji, Studia Polonijne (4) 1981, s. 213 219; Alojzy Miron GOLA, Modlitewniki z Góry św. Anny - inwentaryzacja i typologia, Archiwa Biblioteki i Muzea Kościelne (65) 1996, s. 149-253; Teresa OCHOT, Modlitewniki górnoślaskie do 1914 r., Rocznik Teologiczny Śląska Opolskiego (1) 1968, s. 357-408.

49 Np. P. BUCHWALD-PELCOWA, Z dziejów druku kancjonałów litewskich i cenzury kościelnej w XVII wieku, Rocznik Biblioteki Narodowej (4) 1968, s. 181-195; Zbigniew Jakub LICHAŃSKI, Polskie kancjonaty na Śląsku do końca XVIII wieku. Próba określenia stanu badań, [w:] Ślaskie pogranicza kultur, t. 3. Red. Marian Ursel, Olga Taranek-Wolańska, Wrocław: Atut 2014, s. 51-135.

$50 \mathrm{~Np}$. Zenona RONDOMAŃSKA, Królewieckie druki polskich śpiewników religijnych Kantera z XVIII wieku, Studia Warmińskie (35) 1998, cz. 1, s. 173-183.

51 Np. Stanisław CIEPŁOWSKI, Polskie mszały podróżne XVI wieku, Roczniki Biblioteczne (28) 1976, z. 1/2, s. 85-96.

52 Np. Dariusz KUŹMINA, Katechizmy w Rzeczypospolitej XVI i poczatku XVII wieku, Warszawa: Wydaw. SBP 2002; idem, Wkład jezuitów w upowszechnianie katechizmów w Rzeczypospolitej w XVI wieku, Z Badań nad Polskimi Księgozbiorami Historycznymi (20) 2002, s. 33-46.

53 Np. Janusz DY L, Ksią̇ka hagiograficzna wydrukowana w Polsce do połowy XVI wieku, Nasza Przeszłość (71) 1989, s. 181-212; Renata HOŁDA, Druki religijne z oficyny wydawniczej Teofila Nowackiego w Piekarach Ślaskich, Literatura Ludowa (57) 2013, nr 6, s. 15-33; Olgierd NARBUTT, Historia i typologia ksiag liturgicznych bizantyjsko-słowiańskich. Zagadnienia typologii wedtug kryterium treściowego, Warszawa: Akademia Teologii Katolickiej 1979; Daniel OLSZEWSKI, Ksiązka religijna na terenie Królestwa Polskiego w XIX wieku, Rocznik Świętokrzyski (16) 1989, s. 147-173; Tadeusz PIETRAS, Produkcja katolickiej książki liturgicznej w Polsce od końca XV do połowy XVII wieku, Archiwa, Biblioteki i Muzea Kościelne (39) 1979, s. 171-189; (40) 1980, s. 83-117; (41) 1980, s. 222-241.

54 Np. Zoja JAROSZEWICZ-PIERESŁAWCEW, Starowiercy w Polsce i ich księgi, O1sztyn: Ośrodek Badań Naukowych im. W. Kętrzyńskiego 1995; Jolanta PAW, Wybrane siedem- 
nad książką żydowską. Trzeba tu jednak zaznaczyć, że pod tym pojęciem rozumie się zarówno książkę religijną, jak i wszelką inną napisaną w języku hebrajskim czy jidysz, bez względu na treść, oraz żydowskich autorów tłumaczonych na język polski ${ }^{55}$.

Spośród innych rodzajów książek, które są przedmiotem badań księgoznawczych, syntetycznego ujęcia doczekały się przewodniki turystyczne. Janusz Merski i Jan Paweł Piotrowski przedstawili ich dzieje od najstarszych, XVII-wiecznych, do współczesnych. Przeanalizowali zakres zawartej w nich treści, jej ujęcie, strukturę oraz sposób przedstawiania informacji również za pomocą takich środków, jak ilustracje i mapy. Natomiast Dariusz Opaliński skoncentrował się na okresie zaborów ${ }^{56}$. Nie tylko omówił ich formę zewnętrzną oraz treść opublikowanych wówczas przewodników, lecz także zajął się motywami ich powstawania. Określił ponadto możliwości badania różnych zagadnień dotyczących historii turystyki, jakie stwarza to źródło. Powstało też kilka prac o przewodnikach po Krakowie i jego okolicach ${ }^{57}$,

nastowieczne edycje polskich kancjonałów protestanckich z oficyn Torunia, Królewca i Gdańska, [w:] Studia o bibliotekach i zbiorach polskich, t. 5. Pod red. Bohdana Ryszewskiego, Toruń: Uniwersytet Mikołaja Kopernika 1993, s. 71-88; Roman SĘKOWSKI, Polskie wydawnictwa ewangelickie pogranicza Dolnego i Górnego Ślaska, Kwartalnik Opolski (36) 1990, nr 1/4, s. 60-69.

$55 \mathrm{~Np}$. Monika JAREMKÓW, O potrzebie księgoznawczych badań nad żydowska książa literacka w polskich przekładach $w$ XX wieku, Acta Universitatis Wratislaviensis No 3392, Bibliotekoznawstwo 30, Wrocław 2011, s. 119-132; eadem, Polska czy żydowska? Tożsamość kulturowa książki literackiej na przykładzie serii wydawniczych przekładów z języków hebrajskiego i jidysz, [w:] Kulturowa tożsamość książki. Pod red. Anny Cisło i Agnieszki Łuszpak, Wrocław: Wydaw. Uniwersytetu Wrocławskiego 2014, s. 99-114; eadem, Wydawnictwo Dolnoślaskie jako wydawca przekładów żydowskiej literatury pięknej, Studia o Książce i Informacji Naukowej (34) 2015, s. 27-39; Krzysztof PILARCZYK, Hebrajska książka drukowana w Europie środkowowschodniej w XVI-XVIII wieku: topografia, wielkość produkcji i funkcja, Studia Judaica (10) 2007, nr 1, s. 1-23; idem, Leksykon drukarzy ksiag hebrajskich $w$ Polsce z bibliografia polono-judaików w językach żydowskich (XVI-XVIII wiek), Kraków: Antykwa 2004; idem, Talmud i jego drukarze $w$ Pierwszej Rzeczypospolitej. Z dziejów przekazu religijnego w judaizmie, Kraków: Polska Akademia Umiejętności 1998.

56 Janusz MERSKI, Jan Paweł PIOTROWSKI, Drogi ewolucji drukowanych przewodników turystycznych w Polsce, Warszawa: Almamar - Wyższa Szkoła Ekonomiczna 2010; Dariusz OPALIŃSKI, Przewodniki turystyczne na ziemiach polskich wokresie zaborów, Krosno: Wydaw. „Ruthenos” 2012; wyd. 2, Krosno 2013.

57 Jerzy DUDA, Przewodniki po Krakowie i jego wybranych obiektach w pierwszej połowie XX wieku, Rocznik Krakowski (64) 1998, s. 141-175; Maria KWAŚNIK, Przewodniki po Krakowie i okolicach (od najstarszych do 1945 r.). Charakterystyka, bibliografia, Krzysztofory (19) 1992, s. 164-175; Józef PARTYKA, Dominik ZIARKOWSKI, Z przewodnikiem po okolicach Krakowa. Charakterystyka najważniejszych publikacji wydanych do polowy XX wieku, [w:] „Tu wszystko jest Polska", Kraków 2009, s. 211-230; M. ROGOŻ, Specyfika treści i formy polskich edycji przewodników po Krakowie w latach 1945-1989, [w:] Kraków - Lwów. Książki, czasopisma, biblioteki XIX $i$ XX wieku, t. 10. Pod red. Haliny Kosetki, Grażyny Wrony, Grzegorza Niecia, Kraków: Księgarnia Akademicka 2011, s. 149-163. 
a pokrewnej przewodnikom literaturze podróżniczej swój artykuł poświęcił Krzysztof Migon ${ }^{58}$.

Należy wspomnieć o kalendarzach książkowych, które mają już bogatą literaturę. Przedmiotem licznych prac stały się dzieje poszczególnych kalendarzy ${ }^{59}$ lub ich rodzaje publikowane w pewnej epoce ${ }^{60}$, na pewnym terenie ${ }^{61}$, przez określonego nakładcę ${ }^{62}$ czy dla konkretnej grupy odbiorców ${ }^{63}$. Przeanalizowano też zawartość kalendarzy pod różnym kątem, zazwyczaj według zawartych w nich rodzajów informacji lub pełnionych funkcji ${ }^{64}$. Warto zwrócić uwagę zwłaszcza na publikację Kalendarze staropolskie (Warszawa 2014), wydaną w serii „Staropolskie Teksty Paraliterackie", w której zamieszczono artykuły analizujące zawartość różnorodnych kalendarzy. Tom otwiera porządkujący typologię kalendarzy artykuł Macieja Janika Kalendariografia polska XVI-XVIII wieku. Próba typologii. Należy tutaj dodać, że ten sam autor opublikował kilka lat wcześniej monografię poświęconą kalendarzom astrologicznym doby saskiej ${ }^{65}$, w której przeanalizował

58 K. MIGOŃ, Opis podróży jako typ książki i przedmiot lektury, Czasopismo Zakładu Narodowego im. Ossolińskich 1999, z. 10, s. 135-144.

59 Np. Irena BAR, Józefa Ungra „,Kalendarz Warszawski (1846-1917), Biuletyn Biblioteki Jagiellońskiej (18) 1966, nr 1, s. 39-48; Grażyna MAJ, Znaczenie „,Kalendarza Krakowskiego” Józefa Czecha dla umocnienia więzi narodowej, [w:] Kultura książki w Krakowie doby autonomii galicyjskiej. Pod red. Marii Kocójowej, Wrocław: Wiedza o Kulturze, s. 91-102; Małgorzata FEDOROWICZ, ,Polski Kalendarz Katolicki...” Ignacego Danielewskiego z lat 1862-1897, [w:] Szkice z dziejów piśmiennictwa pomorskiego XVII-XIX wieku. Pod red. Bronisławy Woźniczki-Paruzel, Toruń: Wydaw. UMK 1999, s. 97-109; Agnieszka FLUDA-KROKOS, „Lwowski Powszechny Kalendarz Domowy i Gospodarski” z drukarni Pillerów, [w:] Kraków - Lwów. Książki, czasopisma, biblioteki XIX $i$ XX wieku, t. 9, cz. 2. Pod red. Haliny Kosętki, Barbary Góry, Ewy Wójcik, Kraków: Wydaw. Naukowe Uniwersytetu Pedagogicznego 2009, s. 148-160.

${ }^{60} \mathrm{~Np}$. Bogdan ROK, Kalendarze polskie czasów saskich, Wrocław: Wydaw. Uniwersytetu Wrocławskiego 1985.

61 Np. Krystyna KOSSAKOWSKA-JAROSZ, Dzieje kalendarzy górnośląskich do drugiej wojny światowej, Kwartalnik Opolski (29) 1983, nr 3, s. 32-45; Kazimierz KUBIK, Kalendarze Gdańskie z XVI-XVII wieku, Rocznik Gdański (32) 1972, z. 2 1974, s. 107-155; Teresa LEWANDOWSKA-WILKOŃ, Pierwsze kalendarze książkowe w Zagłębiu Dąbrowskim, Studia Bibliologiczne (1) 1983, s. 72-84; Renata ŻURKOWA, Wokót kalendarzy krakowskich z lat 1614-1630, Rocznik Biblioteki PAN w Krakowie (26) 1981, s. 43-56.

${ }^{62}$ Np. Krystyna HAŁUN, Kalendarze dla Mazurów Jana Karola Sembrzyckiego (18841890), Komunikaty Mazursko-Warmińskie 1981, nr 2/4, s. 259-279; Michał SEWERSKI, Kalendarze Ossolińskie, Rocznik Zakładu Narod. im. Ossolińskich (10) 1975, s. 137-148.

${ }^{63} \mathrm{~Np}$. Roman JASKUŁA, Berlińskie kalendarze dla Polaków w wieku XIX i XX (do 1918 r.), [w:] Historia książki na terenach pogranicza i jej rola w kształtowaniu społeczeństw wielokulturowych. Red. Katarzyna Raczyńska, Zielona Góra: Pro Libris 2005, s. 44-55. Irena TUROWSKA-BAR, O niektórych polskich kalendarzach XIX wieku, Roczniki Biblioteczne (10) 1966, z. 3/4, s. 311-343; eadem, Polskie kalendarze dla kobiet XIX wieku, Biuletyn Biblioteki Jagiellońskiej (17) 1965 , nr 2, s. 37-46.

64 Np. Janina WOŹNICKA, Kalendarze śląskie w walce o utrzymanie narodowości polskiej (1846-1919), Książnica Śląska (23) 1985/1987, s. 107-121.

65 Maciej JANIK, Polskie kalendarze astrologiczne epoki saskiej, Warszawa: DiG 2003.

Roczniki Biblioteczne 60, 2016

(C) for this edition by CNS 
zarówno ich zawartość treściową, jak i formę zewnętrzną, omówił poszczególne elementy kompozycji typograficznej i strukturę wewnętrzną kalendarzy oraz wyróżnił wiele pełnionych przez nie funkcji. W tomie Kalendarze staropolskie znalazł się też artykuł Małgorzaty Gorczyńskiej Kalendarze polskie okresu Oświecenia jako źródto do badań bibliologicznych. Autorka, znana z wcześniejszych badań na temat roli kalendarzy w okresie Oświecenia ${ }^{66}$, wyszczególniła w nim te elementy kalendarzy, które mogą być poddawane badaniom księgoznawczym. Analiza treści i formy kalendarzy ma prowadzić do ustalenia ich roli w przekazywaniu wiedzy i kształtowaniu mentalności czytelników.

5. Poszczególne rodzaje książek omawiane są z różnych punktów widzenia. Wspomniano wcześniej o badaniu repertuarów książki naukowej oraz dla dzieci i młodzieży. Jednym z kryteriów doboru książek do badania jest ich treść. Jako przykład może posłużyć cykl artykułów Marii Wilguszowej dotyczących książki rolniczej i z dziedzin pokrewnych ${ }^{67}$. Wyróżniają się też prace na temat książki literackiej ${ }^{68}$. Ponadto można odnaleźć opracowania poświęcone na przykład książce historycznej, prawniczej, medycznej, żeglarskiej, morskiej, technicznej69.

66 Małgorzata GORCZYŃSKA, Popularyzacja wiedzy w polskich kalendarzach okresu Oświecenia (1737-1821), Lublin: Wydaw. UMCS 1999.

67 M.in. Maria WILGUSZOWA, Książka rolnicza w Polsce, jej powstanie i związki z produkcja (od XVI do końca XVIII wieku). Studium księgoznawcze, Roczniki Biblioteczne (35) 1991, z. 1/2, s. 121-132; eadem, Kształtowanie się nakładów polskich ksiażek rolniczych w XIX wieku, Studia o Książce (18) 1989, s. 119-138; eadem, Produkcja polskiej książki rolniczej w Krakowie w XIX wieku, [w:] Książi, czasopisma, biblioteki Krakowa XIX i XX wieku. Pod red. Ryszarda Ergetowskiego, Kraków: Wydaw. Naukowe WSP 1988, s. 177-195; eadem, Rozpowszechnianie polskiej ksiązki rolniczej w XIX wieku, Roczniki Biblioteczne (31) 1987, z. 1, s. 273-303; eadem, Warszawa jako ośrodek wydawniczy polskich książek rolniczych w latach 1801-1830, Studia o Książce (4) 1973, s. 89-111; eadem, Wydawcy polskich książek rolniczych w XIX w., Studia o Książce (15) 1985, s. 243-269.

68 Elżbieta GONDEK, Polska ksią̇ka literacka na Śląsku pod panowaniem pruskim 1795 1863, Katowice: Wydaw. Uniwersytetu Śląskiego 1995; eadem, Pytania o polska książę literacka na tle ruchu wydawniczego na Śląsu Pruskim w latach 1795-1863, Roczniki Biblioteczne (39) 1995, z. 1/2, s. 49-61; eadem, Zapotrzebowanie na ksiązke literacka w pierwszej połowie XIX wieku w świetle działalności śląskich oficyn wydawniczych, [w:] Śląskie miscellanea. Literaturafolklor. Pod red. Jana Malickiego i Krystyny Heskiej-Kwaśniewicz, Wrocław: Zakład Narod. im. Ossolińskich 1989, s. 71-89; Jadwiga KOWALEWSKA, Repertuar wydawniczy literatury pięknej na ziemiach polskich w czasie I wojny światowej, Wrocław 1992; Jacek LADORUCKI, Książka poetycka jako zagadnienie badawcze. Zarys problematyki, Acta Universitatis Lodziensis. Folia Librorum (12), 2005, s. 51-68.

69 Jacek KUSZŁEJKO, Polska ksiązka historyczna w Rosji w latach 1914-1918, cz. 1, [w:] Instytucje — publiczność - sytuacje lektury, t. 2, Warszawa: Biblioteka Narodowa 1990, s. $172-$ 196; cz. 2, [w:] Instytucje - publiczność - sytuacje lektury, t. 4, Warszawa: Biblioteka Narodowa 1992, s. 225-242; idem, Popularna książka historyczna w latach 1944-1954. Próba charakterystyki, [w:] Instytucje - publiczność - sytuacje lektury, t. 1, Warszawa: Biblioteka Narodowa 1989, s. 186-297; Kazimiera MALECZYŃSKA, Książa historyczna w Polsce 1506-1572, Roczniki 
Innym wyróżnikiem do przeprowadzenia analizy jest język książki. Najwięcej uwagi poświęcono książce francuskiej, przy czym rozumie się pod tym pojęciem zarówno publikacje w języku francuskim, jak i francuskich autorów, tłumaczone na język polski ${ }^{70}$. Zajmowano się ponadto książką rosyjską, angielską, orientalistyczną, białoruską, żydowską ${ }^{71}$. W tym kontekście należy wspomnieć o badaniach nad książką polską poza granicami ziem polskich. Wiele do rozpoznania tego zagadnienia wniosły prace Andrzeja Kłossowskiego, dotyczące publikowanych serii, dzieł określonych autorów i pojedynczych tytułów, działalności wydawców w zakresie polskiej książki, głównie w okresie zaborów ${ }^{72}$. Problematyka ta pojawia się także w publikacjach Oskara Stanisława Czarnika, który z kolei interesuje się głównie książką polską w środowiskach polskich w czasie II wojny światowej i po jej zakończeniu ${ }^{73}$. Obecności książki polskiej w mało poznanym środowisku polskich emigrantów w Niemczech w pierwszych latach po II wojnie światowej poświęcona jest książka Agnieszki Łakomy ${ }^{74}$. Należy też wspomnieć o publikacjach podejmujących problematykę polskiej książki na terenach, które w różnych okresach dziejów utraciły związek z Macierzą ${ }^{75}$.

Biblioteczne (29) 1985, z. 1/2, s. 69-81; Bożena KOREDCZUK, Polska książka prawnicza w XIX wieku — jej zawartość informacyjna i funkcje, [w:] Przestrzeń informacyjna książki. Red. Jadwiga Konieczna, Stanisława Kurek-Kokocińska, Hanna Tadeusiewicz, Łódź: Wydaw. Biblioteka 2009, s. 243-256; A. JAZDON, Książka medyczna w repertuarze wydawców wielkopolskich okresu zaborów (1801-1918), Biuletyn Głównej Biblioteki Lekarskiej (40) 1994, nr 349, s. 57-76; Adam RUTA, Ksiązka żeglarska w Drugiej Rzeczypospolitej, Kraków: Wydaw. Naukowe WSP 2010.

70 Monika RAUSZ, Francuska ksiażka szkolna, fachowa i naukowa w repertuarze wydawniczym Galicji lat 1864-1900, Roczniki Biblioteczne (25) 1981, z. 1/2 s. 41-54; eadem, Ksiązka francuska w repertuarze wydawniczym Galicji (1864-1914), [w:] Kraków - Lwów..., t. 4, s. 74-87.

71 Np. Barbara STOLARCZYK, Ksiażka angielska u wydawcy polskiego w latach 1945 1970, Studia o Książce (8) 1978, s. 197-222. Por. też przyp. 57.

72 Bibliografia prac zob. Ewa JAROSZEWSKA, Publikacje oraz dokumentacja działalności popularyzatorskiej, dydaktycznej oraz organizacyjnej Profesora Andrzeja Kłossowskiego, Acta Universitatis Nicolai Copernici. Bibliologia (2/3) 1998, s. 37-86.

73 M.in. O.S. CZARNIK, Polskie książki naukowe i literackie na Wschodzie. Zakres i kierunki upowszechniania, Przegląd Humanistyczny 2003, nr 5, s. 77-82; idem, Produkcja ksiażek polskich na Zachodzie w połowie lat 90. XX wieku, [w:] Ksiażka, biblioteka, informacja: między podziałami a wspólnotą. Pod red. Jolanty Dzieniakowskiej, Kielce: Wydaw. Akademii Świętokrzyskiej 2007, s. 135-149; idem, $W$ drodze do utraconej Itaki. Prasa, książka i czytelnictwo na szlaku Samodzielnej Brygady Strzelców Karpackich (1940-1942) oraz Armii Polskiej na Wschodzie i 2 Korpusu (1941-1946), Warszawa: Biblioteka Narodowa 2012; idem, Wydawnictwa wychodźców polskich na wschodzie w okresie II wojny światowej, Przegląd Humanistyczny 2009, nr 3, s. 65-80.

74 Agnieszka ŁAKOMY, Polska ksiązka na obczyźnie. Niemcy Zachodnie 1945-1950, Warszawa: SBP 2011.

${ }_{75}$ Maria BABNIS, Książka polska w Gdańsku w okresie zaboru pruskiego 1793-1919, Wrocław: Zakład Narod. im. Ossolińskich 1989; Aleksandra MENDYKOWA, Dzieje ksiażki polskiej na Śląsku, Wrocław: Ossolineum 1991; eadem, Książka polska we Wrocławiu w XVIII wieku, Wrocław: Zakład Narod. im. Ossolińskich 1975. 
Różne typy książek prezentowane są też jako składnik serii wydawniczych. Można wyróżnić opracowania poświęcone pojedynczym seriom lub takim, dla których elementem łączącym jest wydawca, przedział czasowy lub teren, na którym się ukazywały, treść lub grupa odbiorców ${ }^{76}$.

Osobną grupę opracowań tworzą te, których tematem są dzieje wydawnicze utworów określonego pisarza bądź pojedynczych tytułów. Są to zazwyczaj klasycy polskiej literatury ${ }^{77}$ oraz ich najbardziej popularne utwory ${ }^{78}$. Można też odnaleźć prace poświęcone książkom nieliterackim, naukowym i ich twórcom ${ }^{79}$.

6. Stefan Vrtel-Wierczyński, pisząc o kategoriach książki, wyróżnił oprócz książki właściwej także tę w bardziej ogólnym znaczeniu, a wśród jej rodzajów wymienił między innymi druki ulotne. Charakterystyka różnych ich rodzajów i funkcji znalazła się w artykułach zamieszczonych w tomie Druki ulotne i okolicznościowe (Wrocław 2006). W artykule wprowadzającym Krzysztof Migoń oprócz rozważań terminologicznych przedstawił na przykład charakterystyczne

${ }^{76}$ Np. R. CYBULSKI, Serie ksiązek kieszonkowych w Polsce w latach 1966-1970, Warszawa: Biblioteka Narodowa 1972; Anna GRZYBOWSKA, Damian KUŚ, Arcydzieła Polskich i Obcych Pisarzy. Seria wydawnicza oficyny Feliksa Westa w Brodach 1900-1914, Rocznik Zakładu Narodowego im. Ossolińskich (9) 1974, s. 157-186; A. JAZDON, Poznańskie serie wydawnicze, Kronika M. Poznania 1999 nr 1, s. 382-400; Bogumiła STANIÓW, Serie ksiazżek dla dzieci i młodzieży w Polsce jako źródło informacji o świecie, nauce i człowieku (na wybranych przykładach), [w:] Przestrzeń informacyjna, s. 339-353; Jerzy W. ZAWISZA, Wydawnictwo dziet tanich Adama Wiślickiego, Literatura Ludowa (17) 1973, nr 4/5, s. 44-53.

77 P. BUCHWALD-PELCOWA, Dawne wydania dziet Jana Kochanowskiego, Warszawa 1993; Andrzej KŁOSSOWSKI, Francuskie przekłady dzieł zebranych Zygmunta Krasińskiego i Juliusza Słowackiego w edycjach Księgarni Luksemburskiej, Księgarz (17) 1973, nr 3, s. 53-57; idem, Mickiewicz w wydaniach Bolestawa Maurycego Wolffa, księgarza i typografa w Petersburgu, Rocznik Biblioteki Narodowej (14) 1980, s. 115-149; Małgorzata ROWICKA, Wydawnicze losy twórczości Juliusza Słowackiego w latach 1830-1914, Roczniki Biblioteczne (57) 2013, s. 45-76; Józef SZOCKI, Dzieje wydawnicze Marii Konopnickiej w okresie zaborów, [w:] Maria Konopnicka. Pod red. Józefa Z. Białka i Tadeusza Budrewicza, Kraków: Cracovia 1995, s. 115-122; Jan TRZYNADLOWSKI, Juliusza Stowackiego dzieje edytorskie i wydawnicze, Ze Skarbca Kultury (29) 1977, s. 119-132.

78 Np. Zbigniew GOLIŃSKI, Pierwsze zbiorowe wydanie dzieł Krasickiego, Roczniki Biblioteczne (4) 1960, z. 1/2, s. 81-150; A. GRUCA, Wydawnicze dzieje „Wyboru poezyj” Teofila Lenartowicza, [w:] Studia bibliograficzno-bibliologiczne. Pod red. Marii Kocójowej, Kraków: Wydaw. UJ 1995, s. 135-141; Jan WRÓBLEWSKI, Wydanie i kolportaż „Krzyżaków” Henryka Sienkiewicza na Mazurach, Komunikaty Mazursko-Warmińskie 1970, nr 2, s. 283-306.

79 Np. A. KŁOSSOWSKI, Dzieje wydawnicze „Obrazu bibliograficzno-historycznego” Adama Jochera na tle bibliograficznej działalności księgarzy europejskich, „Księgarz” (22) 1977, nr 1, s. 55-67; Henryk ŁAPIŃSKI, Dzieje wydawnicze prac J.M. Ossolińskiego, Rocznik Zakładu Narodowego im. Ossolińskich (8) 1973, s. 29-43; Justyna ŁOPACZYK, Wokót trzech edycji monografii Piotra Chmielowskiego „Adam Mickiewicz - zarys biograficzno-literacki”, Biblioteka (5) 2001, s. 44-54; Małgorzata STOLZMAN, Dzieje wydawnicze „Księgi pamiątkowej jubileuszu J.I. Kraszewskiego z 1879 roku”, Roczniki Biblioteczne (20) 1976, z. 1/2, s. 235-252. 
dla druków ulotnych i okolicznościowych cechy pozwalające na ich identyfikację. Można też odnotować prace zajmujące się albo pewnymi rodzajami druków ulotnych i okolicznościowych występującymi w różnych epokach ${ }^{80}$, albo też ich funkcjami ${ }^{81}$.

W kontekście druków ulotnych należy też wspomnieć o dokumentach życia społecznego. W tym zakresie warto zwrócić uwagę przede wszystkim na prace Anety Firlej-Buzon, która zajmowała się zarówno zagadnieniami teoretycznymi, typologią, jak i poszczególnymi rodzajami oraz zbiorami tego rodzaju publikacji.

Jednym z rodzajów publikacji zaliczanych do dokumentów życia społecznego są katalogi księgarskie i wydawnicze. Pisze się o nich głównie jako źródłach do badania repertuaru wydawniczego i asortymentu księgarń. Powstały też prace o ich cechach i rodzajach ${ }^{82}$.

7. Oprócz bibliologów studia nad różnymi rodzajami książki prowadzą specjaliści z innych dyscyplin: historycy literatury (książka dla dzieci, popularna), nauki (książka naukowa), historycy oświaty (książka dla dzieci, podręczniki), religioznawcy (książka religijna). Badania uczonych wymienionych dyscyplin przynoszą ciekawe wyniki, które mogą być wykorzystane przez bibliologów. Jako przykład można wskazać prace historyków literatury dotyczące literackiej ramy wydawniczej, a zwłaszcza szkoły badawczej, której początek dały studia Renardy Ocieczek $^{83}$.

Również w zakresie książki popularnej badania bibliologiczne wspomagają historycy literatury, którzy zainteresowali się tym pogardzanym niegdyś odłamem piśmiennictwa. $Z$ tego środowiska wyszły opracowania na temat poszczególnych gatunków literatury popularnej. Znajdują się w nich zazwyczaj fragmenty omawiające ich produkcję i rozpowszechnianie. Można wymienić przykładowo

80 Jerzy Wojciech ZAWISZA, Panegiryczny druk okolicznościowy epoki saskiej, Wrocław: Zakład Narod. im. Ossolińskich 1984.

81 Aneta FIRLEJ-BUZON, Druki ulotne i okolicznościowe jako źródta do badań dziejów kultury Dolnego Ślaska lat 1945-1958, Wrocław: Wydaw. Uniwersytetu Wrocławskiego 2013.

82 A. GRUCA, Krakowskie katalogi księgarskie doby autonomii galicyjskiej. Typologia, wartość źródłowa w kontekście przemian form informacji o dawnej ksiażce, [w:] Uniwersum piśmiennictwa wobec komunikacji elektronicznej. Pod red. Krzysztofa Migonia i Marty Skalskiej-Zlat, Wrocław: Wydaw. Uniwersytetu Wrocławskiego 2009, s. 65-75; Maria KONOPKA, Katalogi Księgarni Polskiej we Lwowie, Rocznik Naukowo-Dydaktyczny. Prace Bibliotekoznawcze (8) 1996, s. 27-35; Grzegorz NIEĆ, Antykwaryczne katalogi aukcyjne w Polsce po 1989 r. - ewolucja form i treści (na przykładzie Antykwariatu Rara Avis z Krakowa), [w:] Książka i biblioteka w procesie komunikacji społecznej. Pod red. Renaty Aleksandrowicz i Haliny Rusińskiej-Giertych, Wrocław: Atut 2015, s. 173-203.

${ }^{83}$ Zob. np. Renarda OCIECZEK, Studia o dawnej książce, Katowice: Wydaw. Uniwersytetu Śląskiego 2002; Przedmowa w książce dawnej i współczesnej, pod red. Renardy Ocieczek, Katowice: Gnome 2002; Dzieło literackie i książa w kulturze. Red. Ireneusz Opacki, Katowice: Gnome 2002; Dedykacje w książce dawnej i współczesnej. Pod red. Renardy Ocieczek i Anny Sitkowej, Katowice: Gnome 2006. 
takie publikacje, jak Proza jarmarczna XIX wieku. Próba systematyki gatunkowej (Wrocław 1993) Tadeusza Żabskiego (tu szczególnie rozdział Reguły obiegu literatury popularnej), Koncepcje i rozwój literatury dla ludu w latach 1773-1863 (Bydgoszcz 1996) Eugenii Sławińskiej oraz „Kwiaty zła” na miejskim druku. O powieści zeszytowej XIX i XX wieku (Wrocław 1998) Anny Gemry. W tej ostatniej na uwagę zasługuje rozdział Powieść zeszytowa jako zjawisko wydawnicze opisujący między innymi formę edytorską oraz produkcję wydawniczą. Wiele artykułów mogących zainteresować bibliologów ukazało się na łamach „Literatury i Kultury Popularnej”, serii zeszytów naukowych Uniwersytetu Wrocławskiego. Charakterystykę poszczególnych gatunków literatury popularnej, a ponadto hasła poświęcone jej wydawcom zawiera Stownik literatury popularnej wydany w 1997 roku pod redakcją T. Żabskiego.

Wątki stojące na pograniczu bibliologii można odnaleźć w pracach historyków oświaty, których interesują podręczniki oraz edukacyjny aspekt literatury dla ludu. Na temat książki dla ludu piszą oni przy okazji prezentowania działalności oświatowej różnych stowarzyszeń ${ }^{84}$. Historycy z kolei odnoszą się do literatury historycznej pojawiającej się w repertuarze wydawniczym oraz w publikacjach popularnych ${ }^{85}$. Interesujące dla bibliologa artykuły na temat książki dla ludu i literatury popularnej można znaleźć w opracowaniach etnograficznych ${ }^{86}$. Artykuły z tego zakresu, także o charakterze metodologicznym, pojawiają się na przykład w dwumiesięczniku „Literatura Ludowa”"

\section{UWAGI KOŃCOWE}

Zebrany materiał pozwala zauważyć, że nie wszystkie rodzaje książek znalazły się w jednakowym stopniu w polu zainteresowań badaczy. Wyróżniają się ilością opracowania dotyczące książki dla dzieci i młodzieży oraz książki naukowej. Pojawiają się również prace podejmujące zagadnienie książki popularnej, w tym również dla ludu, a także religijnej, różnego rodzaju podręczników, poradników,

${ }^{84}$ Oto niektóre przykłady takich prac: Krzysztof KABZIŃSKI, Funkcja społeczno-wychowawcza i oświatowa Towarzystwa Czytelni Ludowych (1880-1939), Wrocław: Zakład Narod. im. Ossolińskich 1985; Ryszard TERLECKI, Oświata dorostych i popularyzacja nauki w Galicji w okresie autonomii, Wrocław: Zakład Narod. im. Ossolińskich 1990; Leszek ZASZTOWT, Popularyzacja nauki w Królestwie Polskim 1864-1905, Wrocław: Zakład Narod. im. Ossolińskich 1989.

85 Artykuły na ten temat zawiera np. praca Edukacja historyczna społeczeństwa polskiego $w$ XIX w. Pod red. Jerzego Maternickiego, Warszawa: PWN 1981.

86 Irena MIERZWA, Literatura dla ludu, [w:] Folklor Górnego Ślaska. Pod red. Doroty Simonides, Katowice: Śląsk 1989, s. 303-332.

87 John G. CAWELTI, Koncepcja schematu w badaniach literatury popularnej, Literatura Ludowa (17) 1973, nr 6, s. 44-52; Piotr KOWALSKI, Literatura popularna - propozycja badawcza, Literatura Ludowa (27) 1983, nr 2, s. 15-32. 
kalendarzy. Wyróżnikiem jest tu adresat oraz wiążąca się z tym tematyka i dostosowana do niej szata zewnętrzna. W ramach tych wszystkich rodzajów książek można wskazać pewne częściej podejmowane nurty badawcze. Podstawową kwestią jest określenie cech oraz typologia poszczególnych rodzajów książek, a także ustalenia terminologiczne. Stanowi to punkt wyjścia w badaniach nad poszczególnymi typami książki, przedstawienia ich w rozwoju historycznym oraz jako elementu repertuaru wydawniczego. Kolejnym zagadnieniem są wydawnicze dzieje utworów poszczególnych pisarzy, również jako składnik repertuaru wydawniczego bądź księgarskiego, oraz dzieje pojedynczych tytułów. Utrudnieniem w badaniach, na które zwracają uwagę autorzy analizowanych opracowań, jest brak lub niepełna rejestracja bibliograficzna poszczególnych rodzajów książki. Dotyczy to między innymi kalendarzy, książki popularnej, judaików. Daje się też zauważyć niewielkie zainteresowanie niegdyś popularnymi rodzajami książki chodzi o książkę kieszonkową ${ }^{88}$. W bazie „Polskiej Bibliografii Bibliologicznej” za lata 1995-2010 figuruje tylko jeden artykuł na ten temat, i to niemający charakteru naukowego, a jedynie prezentujący ofertę rynkową. $Z$ kolei baza rejestruje sporo opracowań dotyczących komiksów, a tematyka ta nie była wcześniej zbyt eksponowana w badaniach. Coraz częściej pojawiają się opracowania na temat książki elektronicznej, które albo określają jej cechy, albo pokazują różnice między nią a książką tradycyjną w postaci kodeksu ${ }^{89}$. W tym wypadku należy rozstrzygnąć, w jakim stopniu i jakie zagadnienia związane z książką elektroniczną mieszczą się w polu zainteresowań bibliologii.

ANNA GRUCA

\section{RESEARCH INTO BOOKS AND THEIR TYPES IN POLAND AFTER THE SECOND WORLD WAR}

\section{Summary}

The paper presents an overview of research into books and their types conducted after the Second World War by Polish bibliologists. The scholars were interested mostly in academic books,

88 Seriom książek kieszonkowych obszerniejszą publikację poświęcił Radosław Cybulski. Dokonał w niej ogólnej charakterystyki tego rodzaju książki, programów serii, zagadnień produkcji, rozpowszechniania i odbioru książki kieszonkowej. Zob. R. CYBULSKI, Serie książek kieszonkowych w Polsce w latach 1966-1970, Warszawa: Biblioteka Narodowa 1972.

89 Zob. np. prace Małgorzaty GÓRALSKIEJ, Książka elektroniczna - przeszłość i perspektywy, [w:] Oblicza kultury ksiązki. Kom. red. Małgorzata Komza [i in.], Wrocław: Wydaw. Uniwersytetu Wrocławskiego 2005, s. 11-28; eadem, Funkcjonalność oraz komunikatywność książki tradycyjnej i elektronicznej w perspektywie semiotycznej, [w:] Bibliologia. Pod red. Dariusza Kuźminy, Warszawa: Wydaw. SBP, s. 360-370; Marian WALCZAK, Książka elektroniczna jako nowe zjawisko w kulturze literackiej, Współczesne Problemy Komunikacji i Informacji Naukowej (1) 2010, s. 99-120. 
popular books as well as books for children and young people. They explored their characteristic features, presented them as elements of the publishing repertoire as well as serial publications, and discussed their development in various periods. Less interesting to them were the structure and typology of books. In recent years there have emerged studies devoted to electronic books as objects of bibliological research. Research into books and their types is also conducted by specialists from other disciplines: historians, historians of literature and education. Their results are also interesting to bibliologists.

KEY WORDS: book studies, book structure, book typology 